\title{
ALTERNATIF RANCANGAN MESIN PASTEURISASI SUSU SAPI MENGGUNAKAN METODE QUALITY FUNCTION DEPLOYMENT
}

\section{ALTERNATIVE DESIGN OF COW'S MILK PASTEURIZATION MACHINE USING QUALITY FUNCTION DEPLOYMENT METHOD}

\author{
Joko Slamet $^{1^{*}}$, Ong Andre Wahyu Riyanto \\ ${ }^{1,2}$ Program Studi Teknik Industri, Fakultas Teknik, Universitas Wijaya Putra, Surabaya \\ *E-mail: jokoslamet201294@gmail.com
}

\begin{abstract}
ABSTRAK
Pemerintah menganggap penting sektor usaha mikro, kecil, dan menengah (UMKM) bagi perekonomian Indonesia. Dukungan besar pemerintah terhadap sektor UMKM karena besarnya potensi dan kontribusi sektor UMKM bagi perekonomian Indonesia, khususnya pada salah satu UMKM sektor pemeliharaan peternakan susu sapi perah di Kabupaten Gresik. Namun, mayoritas UMKM tersebut hanya sebatas mengumpulkan (pengepul) susu sapi segar hasil pemerahan kemudian langsung dijual ke pabrik pengolahan susu sapi. Namun, tidak semua susu sapi perah yang dihasilkan oleh UMKM dapat dijual ke pabrik. Bahkan, susu sapi segar yang tidak terjual ke pabrik kadang dijual dengan harga murah bahkan sering terbuang. Apalagi, UMKM juga mengalami kendala masih rendahnya kapasitas produksi pengolahan susu sapi menjadi produk olahan susu sapi segar. Oleh karena itu diperlukan suatu rancangan spesifikasi teknis mesin pasteurisasi yang mampu meningkatkan kapasitas produksi produk olahan susu sapi segar bagi UMKM. Tujuan dari penelitian ini adalah bagaimana menghasilkan suatu rancangan spesifikasi mesin pasteurisasi susu sapi otomatis yang mampu meningkatkan kapasitas produksi dan menghasikan produk yang higienis. Rancangan mesin pasteurisasi susu sapi otomatis yang sesuai untuk kebutuhan sektor UMKM ini masih jarang dilakukan. Oleh karena menjadi hal yang penting dan mendesak untuk merancang spesifikasi mesin pasteurisasi susu sapi otomatis menggunakan metode quality function deployment (QFD). Temuan dari penelitian ini adalah menghasilkan suatu alternatif rancangan spesifikasi mesin pasteurisasi susu sapi otomatis yang berkapasitas 7 liter per jam dan higienis. Dampaknya adalah sebuah rancangan spesifikasi mesin pasteurisasi susu sapi otomatis yang dapat digunakan untuk membuat mesin pasteurisasi susu sapi segar aneka rasa yang bermanfaat bagi UMKM
\end{abstract}

Kata kunci: produktivitas, pasteurisasi susu sapi, quality function deployment, QFD

\begin{abstract}
The government considers the micro, small and medium enterprise (SMEs) sector necessary for the Indonesian economy. The government's great support for the SMEs sector is due to the significant potential and contribution of the SMEs sector to the Indonesian economy, especially in one of the SMEs in the dairy farming sector in the Gresik Regency. However, most SMEs are only limited to collecting fresh milk from milking and then directly selling them to cow's milk processing factories. However, not all dairy cow's milk produced by SMEs can be sold to factories. Fresh cow's milk that is not sold to the factory is sometimes sold at low prices and is often wasted. Moreover, SMEs are also experiencing problems with the low production capacity of processing cow's milk into fresh cow's milk products. Therefore, it is necessary to design a technical specification of a pasteurization machine that can increase the production capacity of fresh cow's milk products for SMEs. This research aims to produce a design specification of an automatic cow's milk pasteurization machine that can increase production capacity and produce hygienic products. The design of automatic cow's milk pasteurization machines suitable for the MSME sector's needs is still rarely done. Therefore, it is important and urgent to design specifications for automatic cow's milk pasteurization machines using the quality function deployment (QFD) method. The key findings of this study are to produce an alternative design of an automatic cow's milk pasteurization machine with a capacity of 7 liters per hour and hygienic. The impact is a design specification of an automatic cow's milk pasteurization machine that can be used to make a variety of flavored fresh cow's milk pasteurization machines beneficial for SMEs.
\end{abstract}


Keywords: productivity, cow's milk pasteurization, quality function deployment, $Q F D$

\section{PENDAHULUAN}

UMKM memiliki peran yang besar dalam menggerakkan perekonomian suatu negara, maka keberadaan UMKM sangat diperlukan dalam sistem perekonomian suatu negara. UMKM juga mampu menyerap jumlah angkatan kerja sehingga dapat mengurangi jumlah pengangguran. Mengingat peran penting UMKM, maka perlu ada suatu upaya untuk meningkatkan produktivitas UMKM agar dapat lebih mandiri dan produktif. Jika masyarakat UMKM sudah berdaya secara ekonomi maka dengan sendirinya beban kemiskinan secara perlahan akan semakin berkurang dan kesejahteraan masyarakat dapat ditingkatkan.

Di Indonesia daerah yang paling banyak menghasilkan produk susu adalah pulau jawa. Meskipun pulau jawa paling banyak menghasilkan produk susu dari pada daerah lain di Indonesia, namun belum memenuhi stok kebutuhan pasar dalam negeri [2]. Menurut Badan Pusat Statistik, Indonesia hanya bisa memproduksi susu segar sekitar 909 ribu ton pada tahun 2018. Masih jauh dari kebutuhan dalam negeri sekitar 3,3 juta ton sehingga sisanya harus diimpor dari luar negeri [2]. Telah cukup banyak upaya-upaya yang dilakukan dalam meningkatkan produktivitas dan pemasran UMKM pengolahan susu sapi segar di Indonesia. Pembuatan mesin produksi produksi susu pasturisasi dan pelatihan produksi bagi UMKM [1]. Pelatihan diferensiasi produk olahan susu sapi bagi UMKM [3]. Strategi pemasaran agroindustri pengolahan susu sapi pada UMKM menggunakan metode SWOT [4]. Meningkatkan pendapatan masyarakat melalui pendampingan UKM produksi permen susu sapi [5]. Perancangan mesin pasteurisasi pengolahan susu sapi segar masih jarang dilakukan. Hanya perancangan alat pendukung pengolahan produk susu sapi berupa rancang bangun sistem otomatisasi penutup botol minuman susu pasteurisasi [6]. Oleh karena itu masih diperlukan suatu penelitian untuk alternatif rancangan mesin pasteurisasi susu sapi segar bagi UMKM menggunakan metode quality function deployment (QFD). Quality function deployment (QFD) adalah metodologi perencanaan yang sering digunakan untuk menafsirkan kebutuhan konsumen menjadi spesifikasi teknis desain produk atau mesin yang diperlukan [7]. Metode QFD merupakan metode yang sesuai dan telah banyak digunakan dalam merancang suatu produk atau mesin untuk memenuhi kebutuhan dan keinginan pelanggan.

Perancangan desain mesin produksi otak-otak bandeng dengan metode QFD [8]. Pengembangan desain mesin opak jepit yang ergonomis dengan metode QFD [9]. Perancangan alat pencacah pepaya muda menggunakan metode FD [10]. Rancang bangun mesin perontok lada dengan metode QFD [11]. Penerapan quality function deployment pada desain mesin pengasapan ikan [12]. Perancangan mesin potong akrilik yang ergonomis dan ekonomis menggunakan metode ergonomic function deployment [13]. Perancangan desain inovasi pada mesin produksi kue pudak berbasis prioritas keinginan konsumen dengan metode QFD dan AHP. [14]. Perancangan mesin penggiling singkong ergonomis untuk operator pada proses pembuatan adonan emping singkong menggunakan metode ergonomic function deployment $[15,16]$. Dalam penelitianpenelitian terdahulu belum pernah dilakukan suatu penelitian mengenai alternatif rancangan mesin pasteurisasi susu sapi skala kapasitas untuk UMKM. Oleh karena itu pada makalah ini diusulkan suatu alternatif perancangan mesin pasteurisasi susu sapi menggunakan metode QFD. Batasan dalam penelitian ini hanya pada alternatif teknis spesifikasi mesin pasteurisasi susu sapi yang sesuai dengan kebutuhan UMKM pada obyek penelitian. Tujuan dari penelitian ini adalah menemukan alternatif spesifikasi teknis rancangan mesin pasteurisasi susu sapi dengan kapasitas produksi yang sesuai dengan kebutuhan UMKM.

\section{METODOLOGI}

Pasteurisasi adalah proses pemanasan makanan dengan tujuan membunuh organisme merugikan seperti bakteri, protozoa, kapang, dan khamir dan suatu proses untuk memperlambatkan pertumbuhan mikroba pada makanan [1]. Quality Function Deployment (QFD) dapat digambarkan sebagai sebuah pendekatan dalam mendesain kualitas produk (product quality design), yang berusaha untuk merubah suara konsumen kedalam Bahasa teknik dan urut-urutannya dalam karakteristik desain. QFD menggabungkan berbagai alat 
desain, keteknikan, dan manajemen untuk membangun produk baru dengan pendekatan dorongan dari konsumen [7]. Metode yang digunakan ditunjukkan pada gambar 1 .

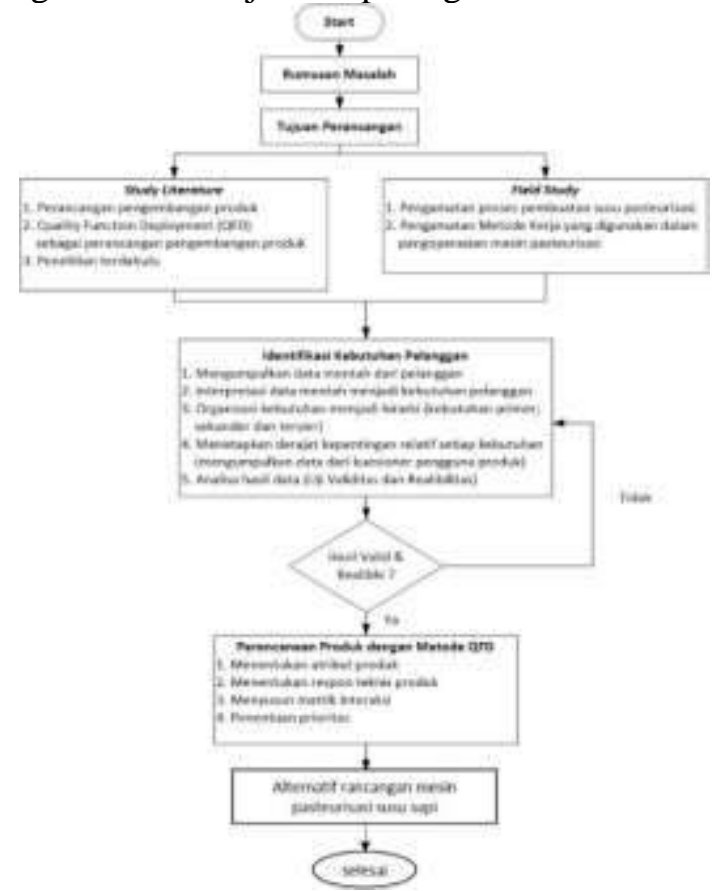

Gambar 1. Metode penelitian

Gambar 1 menunjukkan bahwa pada tahap studi lapangan melalui pengamatan langsung atau peninjauan secara cermat di lokasi observasi di UD. Mitra Wijaya yang berlokasi di Desa Randupadangan Kecamatan Menganti Kabupaten Gresik Jawa Timur untuk memperoleh fakta terkait produktivitas pengolahan susu pasteurisasi aneka rasa.

Identifikasi kebutuhan pelanggan dilakukan dengan wawancara dan focus group discusion (fgd) yang dilakukan bersama dengan mitra. Pada tahap ini tim menggali informasi sebanyak-banyaknya terkait kebutuhan mitra akan perancangan dan pengembangan teknologi tersebut. Pengumpulan data terbagi menjadi beberapa tahap, yaitu: 1)untuk menentukan bobot kepentingan dari kebutuhan konsumen perlu dilaksanakan survey tahap kedua dengan memanfaatkan instrumen berupa kuisioner dan dilakukan uji validitas data. Jika data tidak valid, maka terdapat variabel yang tidak perlu dijadikan bahan pertimbangan dalam menentukan spesifikasi pengembangan produk atau konsumen. Uji validitas dilaksanakan dengan software SPSS. 2) survey dengan kuisioner disertai sketsa dari konsep yang akan dijalankan. Tahapan ini bertujuan untuk mengetahui apakah konsep yang diusulkan mampu menjawab permasalahan masyarakat sasaran. 3)proses observasi produk pesaing serupa yang telah beredar dipasaran, sehingga didapatkan data yang dibutuhkan dari spesifikasi produk secara rinci dan detail.

Pengumpulan data pesaing juga bertujuan untuk membandingkan produk yang telah ada dipasaran dengan produk atau teknologi yang akan dikembangkan. Pada penyusunan konsep pengembangan produk atau teknologi juga diperlukan analisis data pesaing. 4)Melakukan pengumpulan data untuk analisis ekonomi produk atau teknologi tersebut. Tahapan ini dilakukan dengan survey ke agenagen dan toko peralatan untuk mengetahui harga bahan tersebut.

Pernyataan visi dan misi rancangan mesin ini untuk memisahkan antara hal apa yang penting dan yang tidak penting. Menyatakan dengan jelas pasar manakah yang akan dituju dan bagaimana cara menyediakan serta mengkomunikasikan orientasi sebuah produk. Visi dari rancangan mesin pasteurisasi adalah menghasilkan rancangan mesin yang berkualitas berdasarkan kebutuhan kapasitas produksi UMKM. Pernyataan misi dari rancangan mesin adalah mesin pasteurisasi susu sapi yang digunakan untuk memasak susu sapi aneka rasa. Mesin ini memiliki 3 (tiga) chamber yakni chamber pemanas, chamber pendingin dan chamber filling botle. mesin ini melakukan proses produksi pengolahan susu sapi aneka rasa secara otomasi dengan melalui pusat sistem kendali arduino uno.

Kemudian tujuan dibagi dalam beberapa bagian yang meliputi: a)uraian produk: Mesin pasteurisasi susu sapi yang memberikan kemudahan dalam proses produksi, menjaga kualitas proses produksi susu sapi aneka rasa, meningkatkan kuantitas produksi dan menjaga keamanan pengguna mesin. b)Sasaran utama bisnis: memberikan pengalaman baru bagi UMKM pasteurisasi susu sapi aneka rasa, mesin dengan 3 fungsi, meningkatkan kualitas dan kuantitas proses produksi pasteurisasi susu sapi aneka rasa, dan memberikan tingkat keamanan baik dari segi mesin dan operator). c)Pangsa pasar: pasar utama dari produk ini adalah UMKM di Kabupaten Gresik yang memproduksi pasteurisasi susu sapi aneka rasa. Pasar potensial adalah kelompok peternak sapi perah dan pengusaha pasteurisasi susu sapi aneka rasa.

Pada tahap identifikasi kebutuhan pelanggan, dilakukan pembuatan kuesioner berdasarkan dari data yang telah diperoleh melalui observasi, survei dan wawancara 
dengan mitra terkait kebutuhan pelanggan terhadap mesin yang diinginkan. Cara ini dilakukan untuk mengetahui hal-hal apa saja yang konsumen inginkan dari sebuah mesin pasteurisasi susu sapi, baik dalam segi kekurangan maupun kelebihan produk yang sudah ada atau usulan perbaikan untuk mesin yang akan dibuat. Pernyataan-pernyataan yang diajukan terdiri dari 13 pernyataan yang mencakup beberapa dimensi kualitas seperti : performance, proce, servicebillity, feature dan transferablillity. Dimensi kualitas ini kemudian diterjemahkan dalam sebuah skala likert 1-4. Pernyataan kuesioner kebutuhan pelanggan meliputi: 1)Kekuatan material dari mesin pasteurisasi susu sapi. 2)Kemanan material pengolahan pasteurisasi susu sapi (food grade). 3)Kapasitas proses pasteurisasi susu sapi (satu siklus produksi) 7 liter dibandingkan dengan proses pasteurisasi secara manual berkapasitas 3 liter. 4)Kecepatan proses pasteurisasi susu sapi (satu siklus produksi) dalam waktu 1 jam, dibandingkan dengan proses pasteurisasi secara manual memakan waktu 4 jam. 5) Keamanan mesin pasteurisasi susu sapi (mepasi) terhadap pengguna (operator). 6)Keamanan mesin pasteurisasi susu sapi terhadap proses produksi. 7)Tingkat higienitas mesin pasteurisasi susu sapi terhadap produk susu. 8)Desain mesin pasteurisasi susu sapi yang rapi dan mudah dipindahkan. 9)Desain mesin pasteurisasi susu sapi yang menarik. 10)Kemudahan proses pengoperasian mesin pasteurisasi susu sapi. 11)Kemudahan perawatan mesin pasteurisasi susu sapi. 12)Dimensi mesin pasteurisasi susu sapi: P x L x T ( $100 \mathrm{~cm}$ x $50 \mathrm{~cm} \times 120 \mathrm{~cm})$. 13)Harga pembuatan mesin $\leq 12$ juta rupiah.

Pengolahan data quality function deployment (QFD) dimulai dari tahapan spesifikasi produk dengan tujuan mengetahui apa yang harus dilakukan produk mesin pasteurisasi susu sapi untuk menjawab dari kebutuhan pelanggan yang telah teridentifikasi. Beberapa karakteristik yang dirasa sulit di implementasikan dilakukan eliminasi dan karakteristik yang dianggap penting tetap ada. Tahapan spesifikasi produk secara keseluruhan menggunakan metode QFD yang dibagi melalui tiga tahap, yaitu: 1)Menyiapkan daftar metrik, 2)Mengumpulkan informasi tentang pesaing, dan 3)Menetapkan spesifikasi target.

Kemudian menyiapkan daftar metrik kebutuhan. Pada tahapan ini yang perlu dilakukan adalah mencari hubungan antara metrik produk dengan kebutuhan yang telah teridentifikasi, yang merupakan inti dari tahapan spesifikasi produk. Kebutuhan konsumen ditunjukkan pada tabel 1 .

Tabel 1. Daftar kebutuhan konsumen

\begin{tabular}{cl}
\hline No & \multicolumn{1}{c}{ Kebutuhan Konsumen } \\
\hline 1 & Kekuatan material \\
2 & Keamanan material \\
3 & Kapasitas proses produksi \\
4 & Kecepatan proses produksi \\
5 & Keamanan terhadap pengguna \\
6 & Keamanan terhadap proses produksi \\
7 & Tingkat higienitas \\
8 & Desain terhadap transferabillity \\
9 & Desain yang menarik \\
10 & Kemudahan proses pengoperasian \\
11 & Kemudahan perawatan \\
12 & Dimensi \\
13 & Harga pembuatan \\
\hline
\end{tabular}

Tabel kebutuhan konsumen diatas merupakan atribut "apa (What)" yang akan dimasukkan dalam tabulasi QFD (Quality Function Deployment) sebelah kiri, untuk merespon kebutuhan tersebut maka perlu diterjemahkan kedalam atribut atau karakteristik teknis yang akan dimasukkan dalam tabulasi QFD (Quality Function Deployment) sebelah atas yang merupakan atribut "bagaimana (How)".

Tahap selanjutnya mengumpulkan informasi pesaing. Pada tahap ini dilakukan pengumpulan data metrik yang ada untuk mengidentifikasi produk-produk pesaing. Tujuannya adalah untuk membadingkan kelebihan dan kekurangan produk yang sedang dikembangkan dengan melihat produk yang sudah ada dipasaran. Analisis hubungan antara produk baru dengan produk pesaing sangat penting dalam menentukan kesuksesan komersial. Bagian analisis pesaing (competitive benchmarking chart) yang terdapat dalam HOQ (House of Quality) ini dapat diperoleh melalui kuesioner yang disebar kepada 100 responden. Data produk pesaing dapat kita peroleh melalui observasi, observasi yang dilakukan dapat secara langsung ataupun secara online (website atau ecomerce). Gambar 2 adalah pesaing yang menjadi benchmarking, terdapat 3 produk pesaing yang berbeda. 


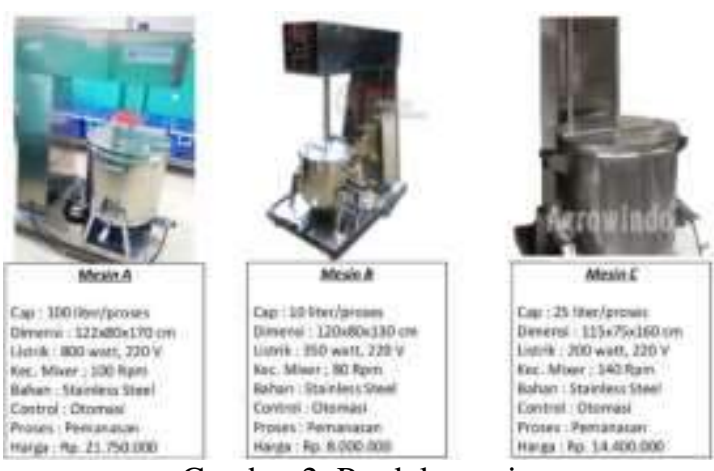

Gambar 2. Produk pesaing

Selanjutnya menetapkan spesifikasi target yang ingin dicapai dalam pengembangan produk mesin pasteurisasi susu sapi aneka rasa. Target performasi dari mesin pasteurisasi susu sapi yang akan dibuat ditunjukkan pada tabel 2 .

Tabel 2. Daftar performansi target yang akan dicapai

\begin{tabular}{|c|c|c|}
\hline No & $\begin{array}{c}\text { kebutuhan } \\
\text { teknis }\end{array}$ & performansi target \\
\hline 1 & $\begin{array}{l}\text { Material food } \\
\text { grade }\end{array}$ & $\begin{array}{l}\text { Material Stainless Steel } \\
\text { SUS } 304 \text { yang bersentuhan } \\
\text { dengan makanan }\end{array}$ \\
\hline 2 & $\begin{array}{l}\text { Tidak banyak } \\
\text { tombol yang } \\
\text { menyulitkan }\end{array}$ & $\begin{array}{l}\text { Meminimalisir tobol } \\
\text { operasional mesin } \\
\text { menghindari kesalahan } \\
\text { pengunaan }\end{array}$ \\
\hline 3 & $\begin{array}{l}\text { Material kokoh } \\
\text { dan ringan }\end{array}$ & $\begin{array}{l}\text { Pemilihan material yang } \\
\text { baik Holo } 4 x 4 \text { Stainless } \\
\text { Steel sebagai rangka mesin }\end{array}$ \\
\hline 4 & $\begin{array}{l}\text { Lebih cepat dari } \\
\text { proses manual } \\
\text { serta mesin lain } \\
\text { yang serupa }\end{array}$ & $\begin{array}{l}\text { Satu mesin mencakup } \\
\text { chamber pemanas, } \\
\text { pendingin dan filling botle }\end{array}$ \\
\hline 5 & $\begin{array}{l}\text { Proses yang } \\
\text { terjaga } \\
\text { kualitasnya }\end{array}$ & $\begin{array}{l}\text { Proses yang tertutup } \\
\text { sehingga tidak ada kuman } \\
\text { atau bakteri yang masuk }\end{array}$ \\
\hline 6 & $\begin{array}{l}\text { Safety terjaga } \\
\text { baik untuk man } \\
\& \text { machine }\end{array}$ & $\begin{array}{l}\text { Terdapat ruang hmapa } \\
\text { udara untuk sirkulasi gas } \\
\text { dan terdapat emergency } \\
\text { buton }\end{array}$ \\
\hline 7 & $\begin{array}{l}\text { Kuantitas } \\
\text { mengikuti } \\
\text { kualitas }\end{array}$ & $\begin{array}{l}\text { Kapasitas masing-masing } \\
\text { chamber } 7 \text { liter sekali } \\
\text { proses produksi }\end{array}$ \\
\hline 8 & $\begin{array}{l}\text { Dimesi mesin } \\
\text { tidak terlalu besar }\end{array}$ & $\begin{array}{l}\text { Dimesi mesin yang tidak } \\
\text { lebih dari } \\
1 \text { meter }\end{array}$ \\
\hline 9 & $\begin{array}{l}\text { Tingkat } \\
\text { ergonomi } \\
\text { terhadap desain }\end{array}$ & $\begin{array}{l}\text { Ergonomi yang mencakup } \\
\text { penggunaan material, } \\
\text { kapasitas dan harga }\end{array}$ \\
\hline
\end{tabular}

HASIL DAN PEMBAHASAN

Tahap penyusunan konsep merupakan gambaran singkat bagaimana produk memuaskan kebutuhan pelanggan. Proses penyusunan konsep dimulai dengan serangkaian kebutuhan pelanggan dan spesifikasi target, dan diakhiri dengan terciptanya beberapa konsep produk sebagai sebuah pilihan akhir. Konsep-konsep disini lebih diarahkan pada cara kerja mesin pasteurisasi susu sapi dengan penggerak motor AC atau DC. Pada prinsipnya proses pembuatan susu pasteurisasi adalah dengan melakukan sterilisasi susu pada temperature $64^{\circ} \mathrm{C}$ dengan melalui proses pemanasan kompor gas dengan dilakukan proses pengadukan secara bersamaan selama proses pemanasan dan pendinginan sampai pada temperature $5^{\circ} \mathrm{C}$. Pemilihan konsep dititikberatkan pada elemen motor, chamber pemanas, chamber pendingin dan chamber filling bottle s3perti pada gambar 3.
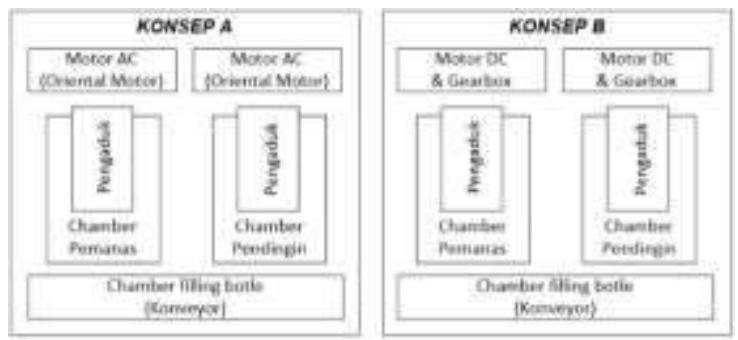

Gambar 3. Konsep mesin pasteurisasi susu sapi

\section{Penyaringan Konsep}

Penyaringan konsep didasarkan pada metode yang telah dikembangkan oleh Stuart Pugh pada tahun 1980 dan sering disebut seleksi konsep Pugh. Tujuan pada proses ini adalah mempersempit jumlah konsep secara cepat dan untuk memperbaiki konsep. Langkah-langkah yang perlu dilakukan yang pertama adalah menyiakan matrik seleksi.

Tabel 3. Matrik penyaringan konsep

\begin{tabular}{lll}
\hline \multicolumn{1}{c}{ Kriteria Seleksi } & \multicolumn{2}{c}{ Konsep } \\
& A & B \\
\hline Hemat listrik & + & - \\
Hasil susu pasteurisasi baik & 0 & 0 \\
Perawatan dan perbaikan mudah & 0 & 0 \\
Tidak mudah rusak & 0 & 0 \\
Penggunaan mudah & 0 & 0 \\
Aman & 0 & 0 \\
Berat & + & - \\
Sistem otomasi & + & + \\
Desain menarik & + & + \\
Harga & + & - \\
Dimensi & + & - \\
Kapasitas mesin & 0 & 0 \\
Jumlah $(+)$ & 6 & 2 \\
\hline
\end{tabular}




\begin{tabular}{|c|c|c|}
\hline \multirow{2}{*}{ Kriteria Seleksi } & \multicolumn{2}{|c|}{ Konsep } \\
\hline & $\mathbf{A}$ & B \\
\hline Jumlah (0) & 5 & 5 \\
\hline Jumlah (-) & 0 & 4 \\
\hline Nilai & 6 & -2 \\
\hline Peringkat & 1 & 2 \\
\hline Lanjutkan? & $\mathrm{Ya}$ & Tidak \\
\hline
\end{tabular}

Pengertian simbol lebih baik dari patokan (baseline) adalah symbol "+" sedangkan simbol lebih buruk dari patokan (baseline) adalah "_“. Simbol sama dengan patokan (baseline) adalah " 0 ". Berdasarkan tabel 3 kedua konsep mempunyai nilai yang berbeda, sehingga dipilih konsep A yang mempunyai nilai tertinggi untuk dijadikan dalam pengembangan mesin susu pasteurisasi susu sapi.

\section{Penilaian Konsep}

Penilaian konsep diperoleh dari hasil kuesioner terbuka yang diberikan kepada 100 responden. Dari konsep yang ada (4 produk) responden diminta untuk memberikan penilaian atau peringkat. Hasil peringkat dapat dilihat pada tabel 4 .

Tabel 4. Hasil penilaian konsep melalui kuesioner terbuka

\begin{tabular}{ccccccccc}
\hline \multirow{2}{*}{ Data } & \multicolumn{2}{c}{ Produk Baru } & \multicolumn{2}{c}{ Pesaing A } & \multicolumn{2}{c}{ Pesaing B } & \multicolumn{2}{c}{ Pesaing C } \\
& Rank & Score & Rank & Score & Rank & Score & Rank & Score \\
\hline 1 & 1 & 4 & 4 & 1 & 3 & 2 & 2 & 3 \\
2 & 1 & 4 & 4 & 1 & 3 & 2 & 2 & 3 \\
3 & 1 & 4 & 4 & 1 & 3 & 2 & 2 & 3 \\
4 & 1 & 4 & 3 & 2 & 4 & 1 & 2 & 3 \\
5 & 1 & 4 & 3 & 2 & 4 & 1 & 2 & 3 \\
.. &.. &.. &.. &.. &.. &.. &.. &.. \\
.. &.. &.. &.. &.. &.. &.. &.. &.. \\
97 & 2 & 3 & 4 & 1 & 3 & 2 & 1 & 4 \\
98 & 2 & 3 & 4 & 1 & 4 & 1 & 1 & 4 \\
99 & 2 & 3 & 3 & 2 & 4 & 1 & 1 & 4 \\
100 & 1 & 4 & 4 & 1 & 4 & 1 & 2 & 3 \\
Total & & $\mathbf{3 6 9}$ & & $\mathbf{1 5 8}$ & & $\mathbf{1 5 1}$ & & $\mathbf{3 3 1}$ \\
\hline
\end{tabular}

Rank 1 mempunyai skor 4 , rank 2 mempunyai skor 3 , rank 3 mempunyai skor 2 , rank 4 mempunyai skor 1 .

Berdasarkan hasil penjumlahan score antara ke empat produk tersebut, produk baru mendapatkan score tertinggi yakni 369 point, sehingga produk baru layak untuk dikembangkan baik dari segi fungsi, desain dan lain sebagainya.

\section{Pengujian Konsep dan Arsitektur Produk}

Pada tahap ini dilakukan pengujian konsep yang merupakan tahap akhir yang memerlukan survei terhadap pelanggan, pengujian konsep bertujuan untuk mengetahui seberapa besar ketertarikan dan minat para pelanggan terhadap produk baru yang kita rancang. Dari hasil kuesioner didapatkan bahwa dari 100 responden menyatakan ketertarikan terhadap produk baru sebanyak 92 responden tertarik dan 8 responden tidak tertarik (tabel 5).

Tabel 5. Hasil kuesioner pengujian konsep

\begin{tabular}{lcc}
\hline \multicolumn{1}{r}{ Alasan tertarik } & Jumlah & \% \\
\hline Hemat Energi & 37 & $37 \%$ \\
Mesin Ringan & 8 & $8 \%$ \\
Sistem Otomasi & 25 & $25 \%$ \\
Desain Menarik & 10 & $10 \%$ \\
Harga Terjangkau & 12 & $12 \%$ \\
\hline Alasan tidak tertarik & & \\
\hline Kapasitas lebih kecil & 8 & $8 \%$ \\
Jumlah & $\mathbf{1 0 0}$ & $\mathbf{1 0 0 \%}$ \\
\hline
\end{tabular}

Dalam menetapkan arsitektur produk sesuai dengan konsep yang dipilih sebelumnya sangat diperlukan pemahaman mengenai kondisi dan fungsi produk. Fungsi-fungsi komponen secara garis besar dapat digambarkan dengan skema produk seperti dibawah ini (gambar 3 dan 4).

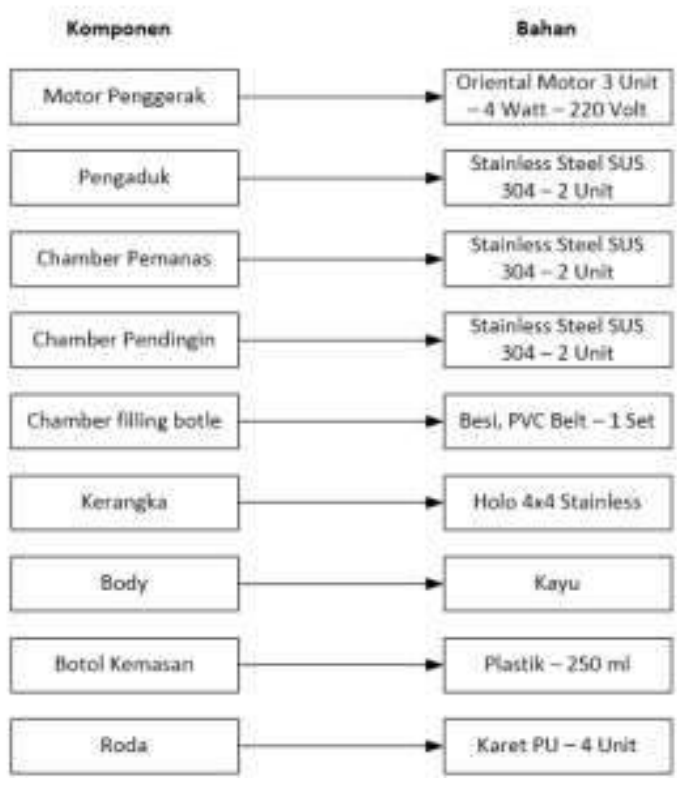

Gambar 4. Morfologi produk 


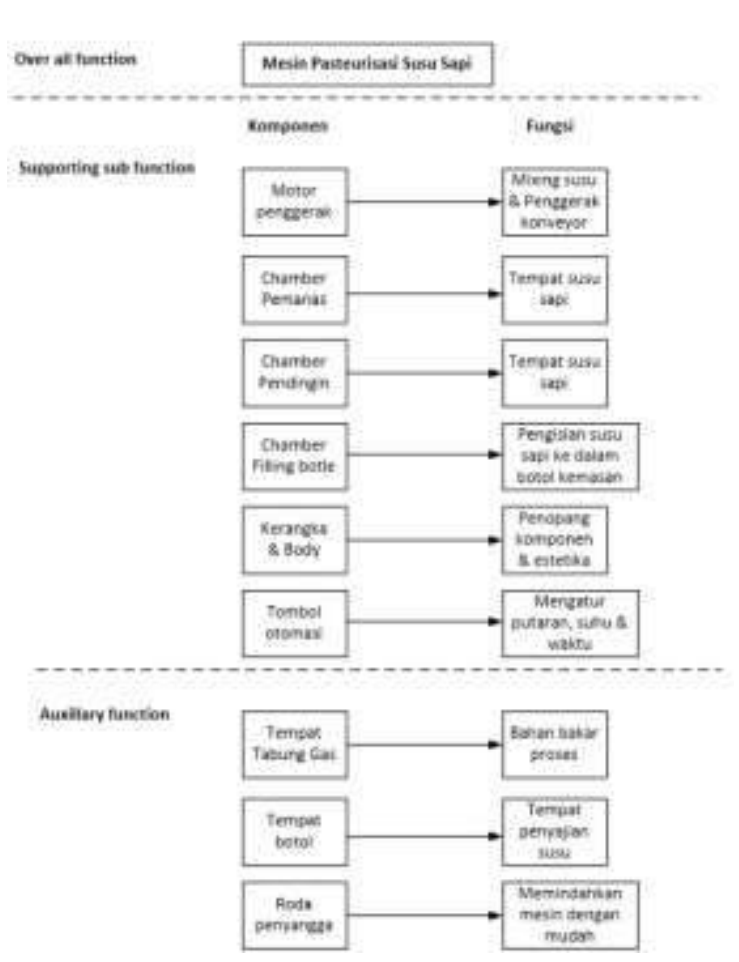

Gambar 5. Arsitektur produk

\section{KESIMPULAN}

Berdasarkan hasil alternatif rancangan dengan menggunakan QFD dapat dikatakan rancangan mesin memiliki keunggulan dibandingkan dengan mesin pasteurisasi susu sapi pesaing lainnya. Alternatif rancangan mesin pasteurisasi susu sapi lebih diunggulkan dibanding dengan tiga produk pesaing lainnya dikarenakan mesin yang dirancang memiliki ukuran yang compact, portable, mudah dipindahkan, satu mesin memiliki 3 fungsi yang dijalankan dengan sistem otomasi, memiliki daya yang rendah dan harga yang lebih terjangkau dari brand produk pesaing lainnya. Perkiraan biaya pembuatan untuk satu unit produk mesin pasteurisasi susu sapi adalah sebesar Rp. 7.500.000,-. Dari total biaya yang dikeluarkan untuk sebuah usaha UMKM dirasa mampu untuk membuat mesin pasteurisasi susu sapi, dikarenakan keunggulan yang dimiliki dapat meningkatkan kapasitas dan menjaga kualitas produksi susu sapi aneka rasa.

\section{SARAN}

Berdasarkan alternatif rancangan desain yang diperoleh dapat digunakan untuk melakukan rancang bangun mesin pasteurisasi susu sapi bagi UMKM pengolahan susu sapi segar.

\section{UCAPAN TERIMA KASIH}

Terimakasih kepada pimpinan program studi teknik industri dan pimpinan fakultas.

\section{DAFTAR PUSTAKA}

[1] Handayani, D., Purwantisari, S., Jannah, S. N., \& Ardiansari, A. (2020). Produksi Susu Pasturisasi MJ9 UMKM Karya Bumi, Mojosongo, Boyolali Bersertifikat MD. Jurnal Pengabdian Vokasi, 1(4), 256-260.

[2] Fauzi, A. Z. (2020). Rekonstruksi Laporan Keuangan Berdasarkan Standar Akuntansi Keuangan Entitas Mikro Kecil Menengah Pada Usaha Peternakan Sapi Perah Bestcow Di Kabupaten Jember (Doctoral dissertation, Universitas Muhammadiyah Jember).

[3] Kustiandi, J., Jaelani, M. I., Khumairoh, N., Pakpahan, N., Azizah, R. N., \& Hafidzoh, S. A. (2020). Peningkatan Kesejahteraan masyarakat melalui pelatihan diferensiasi produk olahan susu sapi desa Ngembal. Jurnal Graha Pengabdian, 2(3), 242-249.

[4] Seta, A. J. STRATEGI PEMASARAN AGROINDUSTRI PENGOLAHAN SUSU DI KECAMATAN MOJOSONGO KABUPATEN BOYOLALI (Studi Kasus di UMKM Finestkee Kefir). Agrista, 7(1).

[5] Suparti, S., Muqorobin, M. M., Wahyuningsih, D., Khoirunnisa, S. I., Setiawan, F. A., \& Handayani, V. (2020). MENINGKATKAN PENDAPATAN MASYARAKAT MELALUI PENDAMPINGAN UKM PERMEN SUSU RINTISAN BUMDES DESA GOGODESO KECAMATAN KANIGORO KABUPATEN BLITAR. Jurnal Graha Pengabdian, 2(1), 78-86.

[6] Akandry, L. D. (2021). TA: Rancang Bangun Sistem Otomaisasi Penutup Botol Minuman Susu Pasteurisasi (Doctoral dissertation, Universitas Dinamika).

[7] Kurniawan, S., \& Nahdi, N. D. (2020). Penggunaan Metode QFD Menerjemahkan Suara Konsumen Untuk Pengembangan 
Lip Product Lavine Beaute. Business Economic, Communication, and Social Sciences (BECOSS) Journal, 2(3), 257266.

[8] MUHAROM, M., \& HINDRATMO, A. (2020). Perancangan Desain Mesin Produksi Otak-Otak Bandeng Dengan Metode Quality Function Deployment. MATRIK: Jurnal Manajemen dan Teknik Industri Produksi, 21(1), 63-72.

[9] Siswadi, S., \& Nugroho, A. (2021). Pengembangan Desain Mesin Opak Jepit yang Ergonomis dan Sesuai Keinginan Konsumen dengan Metode Quality Function Deployment (QFD). JURNAL TECNOSCIENZA, 5(2), 257-272.

[10] Fatkhurrohman,

D.

(2020).

PERANCANGAN ALAT PENCACAH PEPAYA MUDA MENGGUNAKAN METODE QUALITY FUNCTION DEPLOYMENT (QFD). INDUSTRIAL ENGINEERING JOURNAL of the UNIVERSITY of SARJANAWIYATA TAMANSISWA, 4(1).

[11] Darwin, E., Wahyudi, T., \& Sujana, I. RANCANG BANGUN MESIN PERONTOK LADA DENGAN METODE QUALITY FUNCTION DEPLOYMENT (QFD). Jurnal TIN Universitas Tanjungpura, 4(2).

[12] Sari, S. A., Salammia, L. A., \& Indriani, S. (2020). PENERAPAN QUALITY
FUNCTION DEPLOYMENT PADA DESAIN MESIN PENGASAPAN IKAN. Industri Inovatif: Jurnal Teknik Industri, $10(1), 1-5$.

[13] Anshori, H. (2020). PERANCANGAN MESIN POTONG AKRILIK YANG ERGONOMIS DAN EKONOMIS MENGGUNAKAN METODE ERGONOMIC FUNCTION DEPLOYMENT (EFD). Jurnal Surya Teknika, 7(1), 96-103.

[14] Muharom, M. (2020). Perancangan Desain Inovasi Pada Mesin Produksi Kue Pudak Berbasis Prioritas Keinginan Konsumen Dengan Metode QFD dan AHP. Jurnal Mesin Nusantara, 3(2), 62-71.

[15] Riyanto, O. A. W. (2015). Implementasi metode quality control circle untuk menurunkan tingkat cacat pada produk alloy wheel. Journal of engineering and management in industrial system, 3(2).

[16] Caenando, D. P., Mufidah, I., Yekti, Y. N. D., \& El Hadi, R. M. A. (2021). Perancangan Mesin Penggiling Singkong Ergonomis Untuk Operator Pada Proses Pembuatan Adonan Emping Singkong Menggunakan Metode Ergonomic Function Deployment. eProceedings of Engineering, 8(4). 